\title{
Local brand franchise competition in the disruption era
}

\section{N.S. Subawa*}

Department of Economic and Business, Universitas Pendidikan Nasional, Denpasar, Bali, Indonesia

Email: shribawa@undiknas.ac.id

*Corresponding author

\section{N.W. Widhiasthini}

Department of Social Science, Universitas Pendidikan Nasional, Denpasar, Bali, Indonesia

Email: widhiasthini74@undiknas.ac.id

\section{N.P.I. Permatasari}

Department of Economic and Business, Universitas Pendidikan Nasional, Denpasar, Bali, Indonesia Email: intanpermata@undiknas.ac.id

\begin{abstract}
Local brand franchise business, particularly culinary, has been rapidly developed in this disruption era. This is in line with the society's need for delicious but affordable culinary. There is a comprehensive relation-blend of cultural, business, and lifestyle responses. This research examined the factors affecting local brand franchises in the business competition in the disruption era. Using a descriptive qualitative method, the results indicated that local brand franchises are a part of economic disruption, because they create an entirely new market, providing high-quality products at lower prices. In this disruption era, local brand franchises are limited by binding agreements on franchising, courage in creativity and innovation, responsive to instant culture, adaptive to changes in consumer lifestyle, multi-level hegemony, and capitalism.
\end{abstract}

Keywords: disruption; culinary business; franchise; local brands.

Reference to this paper should be made as follows: Subawa, N.S., Widhiasthini, N.W. and Permatasari, N.P.I. (2020) 'Local brand franchise competition in the disruption era', Int. J. Productivity and Quality Management, Vol. 31, No. 4, pp.445-460.

Biographical notes: N.S. Subawa is an Associate Professor of Management at Economics and Business Faculty, Universitas Pendidikan Nasional, Denpasar, Bali, Indonesia. $\mathrm{He}$ is also a researcher and books author concerning on business franchise. He is interested in doing research on consumer behaviour, 
marketing, social change, and practical management. Recently, he has international and national research publication in the form of journal, conference, and books.

N.W. Widhiasthini is an Associate Professor of Economics Social at Law and Social Science Faculty, Universitas Pendidikan Nasional, Denpasar, Bali, Indonesia. Her works in national and international scientific publication, concerning on economic social phenomenon, lifestyle, and social dynamic of society.

N.P.I. Permatasari is a Lecturer of Economics and Business Faculty, Universitas Pendidikan Nasional, Denpasar, Bali, Indonesia. She is interested in doing research about international business management, business English management, 21st century learning and innovation skills, and multimodal literacy. She is actively participated as a presenter and participant on symposium, conference, and any other academic event.

\section{Introduction}

Franchising business development is one of the economic homogeneity phenomena arising in the global society. The capital flow movement through investment is realised by developing business in implementing a franchise business model. Franchising generally involves two parties, the franchisor and the franchisee. The concept of franchising is likened to invisible hands in the global economy. It is the invisible right hand for capitalists that want to control the world economy for expansion and efficient infiltration (Subawa and Widhiasthini, 2019). Instantly developing business and focusing on efficiency are the main franchising business appeals.

Various businesses have been developed with the franchising concept, including those with an international network or pioneered locally in Indonesia. Statistics show a franchise growth of $10 \%$ to $20 \%$ per year. There are 698 franchise businesses, 24,400 units have outlets and a turnover of 172 trillion in 2019 (Media, 2016a). Fernandez and Perrigot (2018) stated that the franchisor uses a website to recruit potential franchisees by displaying information to attract investors. An attractive website reveals the functional benefits of conducting business with a franchise. Serrano and Paul (2018) emphasised that their owners run international franchises. Also, the company expands its business to a unidirectional perspective.

The disruption era has touched the patterns, models, and structure of business development through franchising. Mishra et al. (2018) stated that global business disruption is caused by natural disasters and human actions, which change business models and innovation, disrupting the international business market (Pansuwong, 2020). All franchise aspects have changed in this disruption era. Digitalisation has led to sophisticated technology use by franchise owners, especially those on an international scope. As a result, business opportunities have expanded, causing a shift in consumer and producer roles (Banerjee and Majumdar, 2020).

The conventional pattern of consumer's role as marketers has shifted. Currently, consumers are product marketers using the digital platform. Hu (2019) stated that smart work practices have been created by digitalisation and increased knowledge in using the economy. According to Ranasinghe and Li (2017), it is caused by the high mobility of the 
people initiating drastic changes in capital and geopolitical movements and the hegemony transition. In the franchise business, building design, product uniqueness, tasty foods and drinks, the owner's reputation, and managerial ability in business supervision convince prospective franchisees. Therefore, brand impression becomes essential. Liu and Foreman (2019) stated that the brand attitude is influenced by physical attractiveness, emotions, product experience, and social influence. It causes brand loyalty due to its strong identity influence (Keshtidar et al., 2018). Brand loyalty is then shown through social media, in which consumers show their liking by sharing comments (Abuljadail and Ha, 2019).

To maintain the set tastes, franchise business in food and beverages needs specific direct supervision by the franchisor. Montoya and Stasiewicz (2020) termed it creative entrepreneurship that changes the ecosystem to support creative work. Along with technological advancement in the broad culinary business in Indonesia, some were developed with the concept of franchising, including the local brand franchises. Food and beverage products provide the most significant contribution to franchising growth. Most of the culinary franchises are in the form of restaurants and cafeterias. Statistics show that about $57 \%$ of franchises are registered in the culinary sector. This business is growing due to Indonesia's special ethnic food taste. However, franchise brands are still controlled by foreign investors, with only $16.7 \%$ originating from Indonesia (Media, 2016b).

The development of a culinary business with a franchise model is an interesting field of study because it combines goods and services in product management, developing with basic human needs. Creativity and uniqueness in the culinary business are displayed in terms of its taste, product appearance, building design, service concepts, and ordering manner. Yunus and Pamungkas (2018) stated that lifestyle change determinants are cost efficiency, speed, service value, and simplicity. Tripathi et al. (2020) confirmed that people currently want convenience, comfort, and safety. Modern consumer societies look for alternative lifestyles to get instant gratification (Zhu, 2018).

In local brand franchises, local wisdom is a pledge for the franchisor and the attraction for the franchisee to share economically. Sulhaini et al. (2019) stated that young entrepreneurs' knowledge exploration in developing this local brand by finding the right competitive strategy. This response to people's interest as culinary connoisseurs and customer-oriented uniqueness. It is in line with Oh et al. (2019), who viewed franchising as a cross-cultural study. A holistic perspective is needed to feel the value of services and benefits as experiences felt by customers. Therefore, consumers determine their attitude and loyalty to the franchise business. This research focuses on local brand franchises growing and developing in Indonesia. The study problems are factors affecting local franchise brands in the economic disruption competition era. The study examines the existence of local brand culinary franchise in the economic disruption competition era.

\section{Literature review}

Brookes and Altinay (2017) inspired further studies on franchising. They reveal the institutionalised knowledge transfer in the franchise business, showing the educational process in franchising. Also, Gillis et al. (2020) stated that franchising, as a critical entrepreneurial growth strategy, helps franchisors to have parallel outlets through franchisees. The managerial ability of the franchise manager in idea innovation is vital in assessing business performance. Short et al. (2018) found uniqueness in the number of 
franchise businesses registered by military veterans with insights on entrepreneurship with the concept of franchising. Discipline and perseverance in applying the concept of franchising were also found by Hajdini and Windsperger (2019). It confirms that the franchise business requires control in implementing work contracts, including transactions, exclusive territories, managerial, and binding contract agreements.

Hsu et al. (2017) revealed the strong dominance of the franchisor, stating that the franchisor seeks to maximise the company values through investment management in the tangible and intangible assets at franchise outlets. Accordingly, investors do not make changes as a form of compliance, as also stated by Panda et al. (2019). Yakimova et al. (2019) also emphasised the strong formal franchisor oversight to build trust in the franchisee. This is the complementary relationship between formal and social control in building trust among business partners. According to Nyadzayo et al. (2018), global franchises are accepted as business models in emerging markets. Hoffman et al. (2016) examined the strength of a country's institutional environment affecting the franchise company's international expansion activities by taking locus in the USA. This research shows that international franchising expansion is influenced by variables of political institutions, regulations, infrastructure, economic instability, and political governance. Other factors include state business climate, regulations, taxes, and communication infrastructure. The above research refers to the importance of the discipline of parties, bound in the franchise agreement. The franchisor is disciplined in exercising control while the franchisee complies with the established standards. Trust is the success of developing a franchise business and the strong influence of global factors on international franchise expansion.

Badrinarayanan et al. (2016) revealed that a brand-centric relationship between the franchisor and the franchisee determines the franchise business's success. Gorovaia and Windsperger (2018) found that the choice of the franchise business contract duration and the contract agreement's design help save transaction costs. Cai et al. (2019) stated that franchising systems mostly develop franchises in the fashion industry. The franchisor charges fixed royalties as a prepayment before starting a franchise business. Therefore, there has been an exploration of fixed and variable royalties in this business model, subject to contract management. Perrigot and Basset (2018) emphasised that the franchisor determines franchising's resale price as customer attraction, business chain uniformity, franchisor knowledge, franchisee autonomy, and the legal dimension. Furthermore, Gim et al. (2019) found answers to various parties' doubts about revenue management in the restaurant franchise business. The results indicate that restaurant franchises are more actively involved in earnings management during the growth phase than non-franchise restaurants. The relational performance model developed within the franchise's innovation, and long-term orientation framework is an essential guide (Shockley and Turner, 2016). Hosseini and Moghadam (2017) described equity dimensions influenced by the perceived quality, brand loyalty, image, value, and brand awareness.

Purchasing a franchise is influenced by perseverance, resilience, moderation, geo-social development, and sustainability performance, as established by Kantabutra (2017). Additionally, management should always focus on competence, consistent employee values through training, and providing employees with the opportunity to convey ideas, contributing to the community environment (Kantabutra, 2019). Therefore, franchising business operations are effectively integrated among franchisees by focusing on efficient processes and technology (Ramesh and Ravi, 2017). Kamble and Wankhade 
(2017) asserted that various industries' productivity performance, including franchises, was based on human resources, organisational culture, production, management strategies, and performance. The supply chain helps in the continuity of the franchise business. Apornak and Hezaveh (2019) affirmed that attention is needed at all levels of the supply chain. Ferrer and Santa (2017) added that supply chains must grow and develop competitively by considering dynamic markets. Through franchising, business expansion demonstrates the company's ability to grow to a global scale (Potdar et al., 2017). The previous research is compared with this research, which makes the franchise as a formal object. The difference lies in the specifics learned about franchising. This research focuses more on the factors affecting culinary franchise businesses in competition in the disruption era.

\section{Research framework}

The research framework of this study is as follows.

Figure 1 Research framework

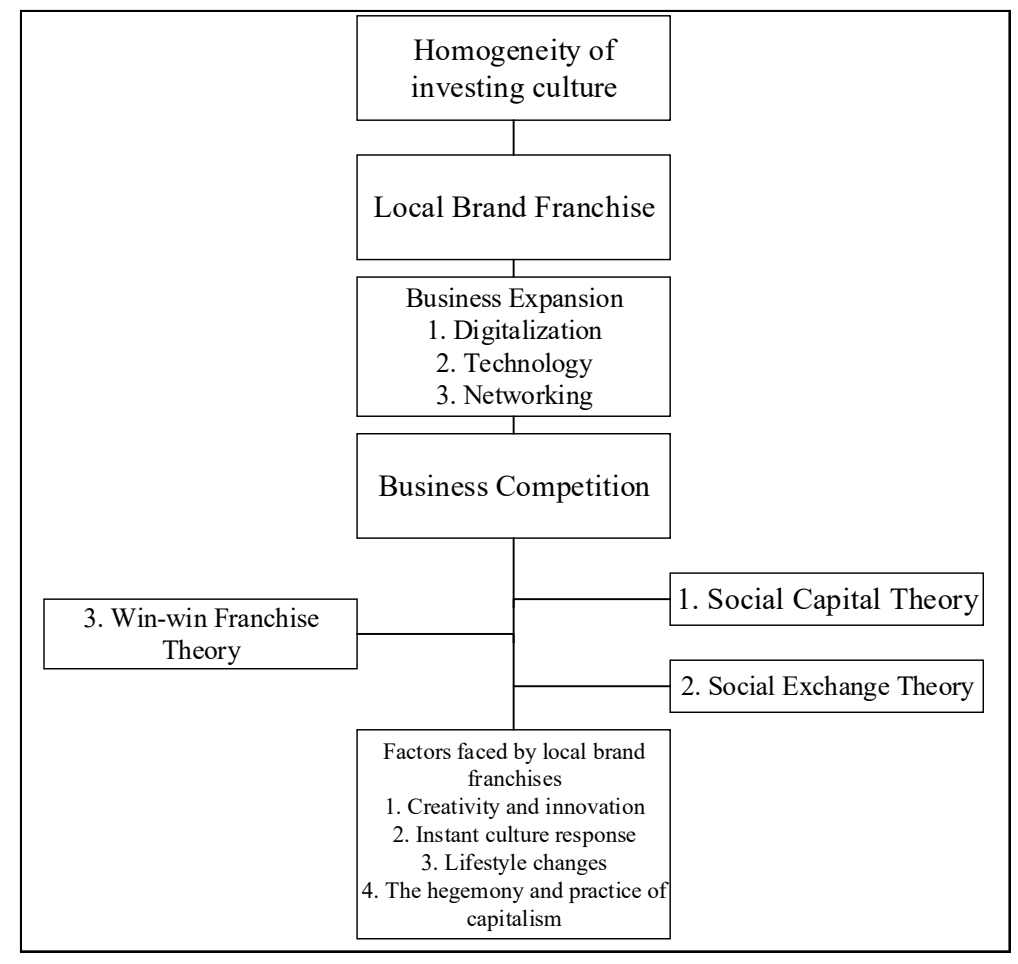

In the flowchart above, the inventory culture homogeneity triggered the development of a local brand franchise business, which is also expanding through technology to build business networks. In business competition, local brand franchises implement win-win franchise, social capital, and social exchange theories. They aim to maintain their existence and the relationship between the franchisor and the franchisee in a business 
agreement. Local brand franchises always pay attention to creativity and innovation. They must always be responsive to the immediate community culture and lifestyle changes in franchisees and the business's consumers. The practice of hegemony through the capitalist network is a factor encompassing local brand franchises.

The relevant conceptual definitions in this study are, disruption era is changed, producing something new, leading to digitalisation. The local brand franchise is a business development model that transfers rights to local brands and their participatory components. They are transferred from the brand rights owner to other parties, as outlined in the agreement concerning both parties' rights and obligations. Culinary business is an activity engaged in providing food, drinks, and other symbolic values attached to the product sold.

There are several theories referred to and used in this study, such as social capital theory in human activities by Bourdieu. This theory uses four capitals, including economic, social capital in relationships, cultural capital, knowledge and skills, and symbolic capital realised in prestige and imaging. These four are used, exchanged, and obtained by the franchisor and franchisee bound in a franchise agreement. The second theory is the social exchange theory, emphasising social exchange in social life activities. This happens in franchise practices, including the resources exchange, social behaviour, business management, intellectual property rights, and the principle of justice (Uli et al., 2017). The assertion was supported by Nyadzayo et al. (2016), stressing that brands are at the centre of franchise business success, focusing on branding in business-to-business (B2B) exchange to integrate social exchange theory. The win-win franchise theory was also reviewed in this study. It emphasises the importance of understanding the balance of benefits between the franchisor and the franchisee, for a sustainable and mutually beneficial relationship (Jang and Park, 2019).

\section{Research methodology}

This study used descriptive qualitative analysis technique. The data was collected through observation, in-depth interviews, and documentary studies. The setting of this study was in Denpasar City, Bali, Indonesia. The city was chosen because it has many local brand franchises, specifically in the culinary business (food and beverage). Most of the culinary franchises have unique designs and concepts in offering good services. Moreover, the local culinary brand franchise was chosen as the study object due to its unprecedented expansion. It is not fully dependent on digitalisation, but rather retains a touch of local wisdom such as the brand of Mi Gacoan and Mi Kober. A total of 15 informants were determined purposively based on their competence, capacity, and capability toward the phenomenon studied. The informants consisted of franchise brand owners, local brand culinary franchisors, and regular customers. Others included visitors from several groups such as professionals and students that were determined intentionally based on knowledge, experience, frequent product consumption, and visits made. Data validity test was run using triangulation on observation and field data, and theoretical studies. The data collected underwent reduction, then analysed with relevant theories. It was presented as a narrative and discussed with a theoretical approach. 


\section{$5 \quad$ Result and discussion}

Franchise business considers multidimensional elements such as distance between outlets, trust, and system performance, determined and agreed upon by both parties. It is the choice for investors and capital owners that want to own a business with a minimal possibility of failure. Weaven et al. (2018) and Kretinin et al. (2019) stated that the beliefs, attitudes, and self-abilities of entrepreneurs influence the choice of business forms, dependency on franchisors, and management of resources that cannot be separated in the franchise system. This research focuses on factors affecting local brand franchise in the economic disruption competition era. They include creativity and innovation, response to instant culture, lifestyle changes, hegemony, and the practice of capitalism. They are explained as follows.

\subsection{Creativity and innovation}

The franchisor is the first party to produce creative and innovative culinary business work, starting from building a business, management concept, interior design, promotion strategy, menus offered, ways of serving, and measurement to produce a standardised taste. On the other hand, creativity and innovation are also difficult for franchisees to carry out. Businesses with a franchise model are identical to franchise buyer compliance with agreements determined by the franchisor. These include selling the specified menus, standardised interior appearance, sticking to the set, and obeying various regulations. Therefore, the franchisee must comply with and adhere to the standard operating procedures (SOPs) set by the franchisor. Control is exercised by the franchisor in a certain period, as stated by Karmeni et al. (2018). The franchisor encourages the creation and innovation of knowledge for the franchisee as part of the control application in the business.

Innovation in franchising is the action and the main role of the franchisor. Franchisors give franchisees innovation opportunities to present ideas and opinions on sales increments. They are approved and implemented in the franchise system. The process of innovation takes place in two-way communication. In Bali, as a world tourist destination, the culinary business developed by the franchise in a variety of processed noodles, ranging from non-spicy to very and super spicy. This is seen from the mode of serving, while the degree of spiciness shows this culinary business's creativity and innovation. Informant $\mathrm{R}$, as a restaurant owner and a franchisee selling spicy noodles, revealed that he sold the same menu as the one offered by the franchisor.

The emerging reality is explained by the social capital theory created by Bourdieu, stating that there is an exchange by having economic capital. Therefore, the franchisee gets social capital through meaningful relationships. Second, the franchisee gets cultural capital, including knowledge and skills on the franchise business concept. Third, the franchisee gets symbolic capital in the form of social prestige by owning a local brand franchise outlet. This is attributed to the social exchange theory, that social exchange is inherent in all social life. This happens in franchise practice as the exchange of valuable resources. Before buying a noodle restaurant franchise, the franchisee first studies the tastes of Balinese that prefer spicy food. It is, therefore, believed that the franchise business purchased is profitable and grows fast. According to research observations in 
line with other informants, a section of the Balinese is pleased with spicy food. On the other hand, they are adaptive to changes, in which eating noodles also make someone full. In this case, there has been acculturation in the selection of food tastes by consumers.

Bundy (2017) established that food acculturation influences shopping behaviour. This is closely related to local brand franchise entrepreneurs' creativity in selling processed noodles with various degrees of spiciness and taste. Informant $\mathrm{R}$ also stated that menu creativity is carried out with the franchisor's permission. Bergfeld et al. (2020) highlighted that when franchising is a transition for entrepreneurs, the franchisee is more satisfied in case the decision to become an entrepreneur is independent. Referring to this condition, in this era of disruption, creativity, and innovation not only become the domain of the franchisor but is implemented by the franchisee with the franchisor's permission. Very different conditions emerged before the disruption era, at a time when the franchisee's creativity could not be carried out. Strict control is exercised by the franchisor as part of the learning process, operationally and managerially. As a result, there are improvements in the quality and quantity of business as an essential part of generating new ideas, innovation, and creativity. This is relevant to the win-win Franchise Theory, which emphasises a mutually beneficial relationship between the two parties.

An integrative knowledge management model among franchisors, franchisees, and customers are applied in the franchise business. There has been development, transfer, and adoption and the use of knowledge in franchising. According to Mohammed and Ahmad (2019) and Santiago et al. (2020), a prospective franchisee that wants to buy a franchise outlet, could be rejected by the franchisor. The franchisor's decision to choose, select, and determine the franchisee is closely related to the brand image. Furthermore, in several cases, prospective franchisees are motivated to start a business independently or later choose to buy another brand franchise. In this condition, they continue to be creative and innovative, considering all the existing opportunities.

\subsection{Instant cultural response}

Instant culture always follows the existence of a franchise business. It is a strong reason for business people, investors, and entrepreneurs to choose that method. Referring to the results of research (Subawa et al., 2020), consumer societies' behaviour has transformed based on the desire for the hedonism that is influenced by instant culture. Franchises buy a ready-made business, ready to run without building a new brand, brand awareness, branding, promotion, and other things needed to start a new business. When deciding to buy a franchise, all franchisor business elements are run and implemented by becoming the franchisee. Comfort and trust become the main attraction of the franchise business. Sriram et al. (2018) and Lertkornkitja (2017) stated that franchising is a cost-effective business, considering the franchisee selection based on the binding price, type, and qualification of the franchise agreement and geographical distance.

Franchisors and franchisees want quick profits. After immediate results, they do not see the need to start a business from scratch. Similarly, the franchisor wants the business network to develop quickly, without building their branches using their own capital. The SOP provides detailed business regulations that must be followed by the franchisee. As compensation, the franchisor receives a royalty fee from the franchisee, as evidenced in the transformation of business activities (Mishra, 2019). 
In the culinary business, many local brand franchises are preferred by the community, becoming franchisees themselves. Strict surveys and selection are applied by franchisors to potential franchise buyers. The franchisor uses digital recruitment through a website and considers the background and characteristics of potential franchise buyers. This is related to the implementation of operational and quality standards, ranging from taste, menus, and food packaging that must remain the same. Strictness in selecting prospective franchise buyers, conducted with conventional methods, and familiarising with the buyer characteristics, is not entirely performed online. Subawa and Mimaki (2019) examined micro, small and medium enterprises (MSMEs) based on the importance of small business implementation and information technology in developing markets through emarkets. Brochado et al. (2018) stated that local brand franchises' development is a mixture of traditional and instant business patterns.

This local brand franchise began as a small business and expanded through the franchising concept. In the local brand franchise business, it is easier to carry out direct communication with the franchisor. According to several informant statements, the business is easily run by buying a local brand franchise, such as a restaurant with a regular noodle menu. There is no need to think about recipes, variations of processed noodles, interior concepts, and employee uniforms, which incidentally must be prepared when starting a business from scratch. Therefore, only the strategic restaurant location and the necessary capital are considered, while the rest is regulated in the business SOP. Determining the exact location is an essential consideration of the franchisor in approving. According to Wiese (2017), consideration of potential market conditions' advantages and disadvantages is related to the franchise business location, and the institutional risks faced. Instant culture is observed in the consumer behaviour of local restaurant franchises selling a variety of noodle-based menus. Buyers come to feel the practicality of the foods offered by the restaurant. Consumers eat without worrying about the lack of nutritional intake. Serving involves using disposable paper plates, spoons replaced with bamboo chopsticks.

Consumers enjoy various menus offered, complete nutritional content, such as carbohydrate elements, vegetable protein, and meat mixed into one in a variety of processed noodles. As a newly recognised brand, it is necessary to pay attention to the consumer lifestyle. Some informants preferred consuming processed noodle products because they are practical and takes a short time. They also do other activities, such as classwork or assignments from campus. In this case, customer satisfaction is reflected. According to Park and Noh (2018) and Zhu (2018), instant culture influence is a combination of satisfaction and perception of consumer social support. Due to high consumer mobility, people also want to consume instantly. This is explained by social exchange theory in the exchange of valuable resources. It is developed based on three assumptions, including social behaviour exchange, individuals try to maximise rewards and minimise costs. The study site's situation shows that quality products are purchased at minimal costs according to consumer needs.

\subsection{Lifestyle changes}

The disruption era directing digitalisation in various activities causes lifestyle changes. Consumers of the local brand franchise culinary business adapt to shifting food consumption patterns, influenced by lifestyle changes. In practice, choosing a restaurant is not only aimed at meeting food needs. There are considerations of consumers when 
consuming food, such as attractive display, a unique, comfortable, and elegant restaurant design, and internet accessibility. Taking selfies before meals and sharing information on social media is a matter of pride. The uniqueness of the service concept and various other features also attracts consumers. Lifestyle changes include reduced carbohydrates such as rice, making noodles a consumer choice. From research observation in several local brand franchise restaurants rapidly growing in Denpasar, most of the consumers are students and professional workers with minimal meal times.

Roja (2020) reported that social media unites customer segments with diverse interests and mindsets. This happens by changing the marketing concept by involving consumers as marketing agents, promoting eating places, and indirectly sharing positive stories with other consumers. As the culinary business owner, the informant stated that most of the consumers were office workers and students, conducting their activities in groups. Therefore, the availability of adequate internet access in restaurants is essential.

Customers were also interviewed on their choice of this local restaurant as a hangout point and a discussion place. They cited its uniqueness in menu, different and new interior design compared to other monotonous international networked restaurants. According to them, international chain restaurants are expensive and bring nothing different. This study shows that developing a local brand franchise receives a good response because of its direct awareness of consumer's needs. Local brand franchisees consider consumers' economic capabilities, the need to fulfil lifestyles, the bandwagon culture among consumers, and prestige. Therefore, they have the opportunity of being internationally developed. Baena (2018), Maček et al. (2019) emphasised that franchisors can expand their business abroad and enter new markets. Many choose markets in developing countries by applying brand standards. Regarding pricing, the food at local brand franchise restaurants is cheap and of quality. This is also why consumers choose the local brand franchise restaurants, making the franchise outlet business performance improve.

The high pricing strategy is maintained on several products to retain consumer confidence. Consequently, consumers believe they are using high-quality products. Local brand franchises also consider local wisdom, especially the food taste needs with their peculiarities, used as a mainstay in marketing. For instance, serving a menu made from noodles with various degrees of spiciness. The more spicy-taste the food, the more expensive it is. Changes in the preparation and naming of food and beverages pose a challenge to consumers, especially young people who want to enjoy the new spicy menu. Therefore, local brand franchises set unique marketing strategies for people to continue consuming the products. They have realised changes in consumer lifestyles, which consider various food consumption factors, leading to consumerism lifestyle practices.

\subsection{Hegemony and practice of capitalism}

The capitalism discussion is about understanding the individual and group efforts to gain profits in the current industrialisation and digitalisation era. It is achieved by utilising the power of information technology in investment and business expansion for profit realisation. Subawa and Widhiasthini (2020) stated that consumer hegemony in this disruption era is strengthened through social media and applications. In franchise business activities, capitalism and hegemony are inseparable because franchisors practice hegemony with franchisees. Various considered factors are stated in the franchise agreement document, including the franchisee's compliance with the procedures set out 
by the franchisor. This is the franchisor's effort to develop B2B relationships (Rahatullah and Raeside, 2018).

Capitalism hegemony is strong in the local brand franchise, according to Roussety et al. (2020). It is a single unit of risk created through the franchisor's delegation of functions to the franchisee. Risk factors in franchising are also formed in layers and are hierarchical. There is multi-level hegemony in franchises, including local brand franchises, as franchisor hegemony to the franchisee, and then passed on to consumers. The restaurant, serving as the main menu of noodle-based preparations developed by a local brand franchise, practices hegemony. It is a form of mastery of certain groups (those who carry out hegemony) to other groups (those who experience hegemony) by using non-physical leadership, prioritising intellectual elements, consensus and agreement on established values. Hegemony is practiced in local brand franchise restaurants to consumers through various social media (Instagram, Facebook, and others) containing significant discount content.

According to Minnema et al. (2017), consumer buying behaviour is evidenced by the number of purchases and brand choices, resulting from promotions, premium bonuses, and price discounts. Another factor is the collaboration between restaurants and fin-tech payment companies, such as OVO, Dana, and Go-Pay. Increasingly using digital payments, consumers get more cash back. An informant admitted a preference to pay with OVO to get more cash in return. This restaurant often carries out promotions and offers significant discounts, restaurant owners are happier when consumers pay using fin-tech, because it minimises the availability of coins, and is far more practical. Subsequently, local brand franchises have adopted marketing patterns, such as international network franchises. Tournois and Forterre (2019) stated that local brand franchises are developed to international standards to produce positive consumer attitudes.

Based on research observations, all employees obeyed the standards applied by restaurant owners, such as wearing uniforms, greeting customers kindly, sending food orders using information systems, calling consumers ready to take orders, and asking consumers to queue in an orderly manner. It is essential to pay attention to the right franchisee's selection process, showing the entrepreneurial orientation to be owned by the franchisee. Business orientation owned by the franchisee can improve the franchise performance, producing the expected benefits. In initiating these business operations, local brand franchises have built a network of economic capitalism, including promotion through social media, high-tech payments by companies, online motorcycle taxis such as Go-Jek and Grab. Local brand franchises are given food and drinks while waiting for orders when cooperating with online motorcycle taxi drivers. Therefore, this restaurant provides a place to serve orders from motorcycle taxis online and get priority services. A shared economic model is therefore formed, which is identical to the disruption era.

\section{Research findings}

The local brand franchise expansion through digitalisation is not entirely valid. Local wisdom received considerable attention, such as popular food tastes in the community, and the appearance concept of building design. Local franchise brands sell cheap products by complying with international network franchise standards. This confirms that the concept of costly high-quality products does not apply to local brand franchise 
development. The sharing economy concept is applied as a business icon in the disruption era, carried out through cooperation with fin-tech companies, online motorcycle taxi operators, social media providers of both companies and individuals with many followers. Consumers also act as marketing agents through their testimonials on visiting, experiencing the services, menus, and uniqueness of local brand franchises. These are uploaded on their social media.

\section{Conclusions, limitations, and future research}

It can be concluded that several factors affect local brand franchises in competition in this disruption era. Creativity and innovation are limited by the franchise agreement binding system. The franchisee must receive the franchisor's permission in order to innovate. There is creativity in various local brand franchises, such as menu variations, outlet designs, and service ways more varied than international network franchises. Local brand franchises respond to instant culture and move quickly to find investors who want a new business without starting from scratch. Local brand franchisees meet consumers' needs with limited time, serve quickly, and provide fast food containing enough nutritional content. They adapt to changes in consumer lifestyles that have shifted from consumption to consumerism. Therefore, consumers consider various factors before making a purchasing decision, such as pride, self-image, and comfort. There are hegemony and capitalism in expanding local franchise brands in the disruption era, created through a multi-level hegemony pattern from the franchisor, through the franchisee, to consumers.

This research was limited to local franchises engaged in the culinary business. It was tied to examining local brand franchises as a business network that started in Indonesia. It recommends further research on the expansion of local brand franchise businesses in various other sectors, not only local brand franchises in the culinary business. Thus, theoretical and managerial implications can be developed in a dynamic and global franchise management. This would contribute to thoughts and develop a more comprehensive science. Also, there is a need to examine the expansion of local franchise businesses that start outside Indonesia to determine a geopolitical perspective.

\section{References}

Abuljadail, M. and Ha, L. (2019) 'Engagement and brand loyalty through social capital in social media', International Journal of Internet Marketing and Advertising, Vol. 13, No. 3, pp.197-217.

Apornak, A. and Hezaveh, M.A. (2019) 'Extension of the model of manufacturing supply chain quality management: an empirical study', Int. J. Productivity and Quality Management, Vol. 28, No. 4, pp.417-437.

Badrinarayanan, V., Suh, T. and Kim, K.M. (2016) 'Brand resonance in franchising relationships: a franchisee-based perspective', Journal of Business Research, Vol. 69, No. 10, pp.3943-3950.

Baena, V. (2018) 'The effect of franchisor characteristics and host country features on the foreign entry mode. Lessons from the Spanish franchise system lessons from the Spanish franchise system', International Journal of Business and Globalisation, Vol. 20, No. 4, pp.457-478.

Banerjee, R. and Majumdar, S. (2020) 'Determinants of shareholder value creation - platform versus traditional business models', International Journal of Business Performance Management, Vol. 21, Nos. 1-2, pp.230-244. 
Bergfeld, A., Lutz, E. and Scheck, B. (2020) 'Social franchising: a transitional solution for organisational growth of social entrepreneurial organisations?', International Journal of Entrepreneurial Venturing, Vol. 12, No. 1, pp.17-38.

Brochado, A., Santos, M., Oliveira, F. and Esperança, J. (2018) 'Gambling behavior: instant versus traditional lotteries', Journal of Business Research, July, Vol. 88, pp.560-567.

Brookes, M. and Altinay, L. (2017) 'Knowledge transfer and isomorphism in franchise networks', International Journal of Hospitality Management, April, Vol. 62, pp.33-42.

Bundy, L. (2017) 'Expatriates go shopping: food and shopping acculturation', International Journal of Retail \& Distribution Management, Vol. 45 No. 10, pp.1079-1094, https://doi.org/10.1108/IJRDM-08-2016-0127.

Cai, Y.J., Chen, Y., Siqin, T., Choi, T.M. and Chung, S.H. (2019) 'Pay upfront or pay later? Fixed royal payment in sustainable fashion brand franchising', International Journal of Production Economics, August, Vol. 214, pp.95-105.

Fernandez, B.L. and Perrigot, R. (2018) 'Using websites to recruit franchisee candidates', Journal of Interactive Marketing, May, Vol. 42, pp.80-94.

Ferrer, M. and Santa, R. (2017) 'The mediating role of outsourcing in the relationship between speed, flexibility and performance: a Saudi Arabian study', Int. J. Productivity and Quality Management, Vol. 22, No. 3, pp.395-412.

Gillis, W.E., Combs, J.G. and Yin, X. (2020) 'Franchise management capabilities and franchisor performance under alternative franchise ownership strategies', Journal of Business Venturing, Vol. 35, No. 1, https://doi.org/10.1016/j.jbusvent.2018.09.004.

Gim, J., Choi, K. and Jang, S.C.S. (2019) 'Do franchise firms manage their earnings more? Investigating the earnings management of restaurant firms', International Journal of Hospitality Management, May, Vol. 79, pp.70-77.

Gorovaia, N. and Windsperger, J. (2018) 'The choice of contract duration in franchising networks: a transaction cost and resource-based view', Industrial Marketing Management, November, Vol. 75, pp.125-133.

Hajdini, I. and Windsperger, J. (2019) 'Contractual restraints and performance in franchise networks', Industrial Marketing Management, October, Vol. 82, pp.96-105.

Hoffman, R.C., Munemo, J. and Watson, S. (2016) 'International franchise expansion: the role of institutions and transaction costs', Journal of International Management, Vol. 22, No. 2, pp.101-114.

Hosseini, M.H. and Moghadam, N.S. (2017) 'A model of customer-based brand equity: evidence from the banking service in Iran', Int. J. Productivity and Quality Management, Vol. 21, No. 1, pp. 23-44.

Hsu, L., Kaufmann, P. and Srinivasan, S. (2017) 'How do franchise ownership structure and strategic investment emphasis influence stock returns and risks?', Journal of Retailing, Vol. 93, No. 3, pp.350-368.

$\mathrm{Hu}, \mathrm{R}$. (2019) 'Spatial disruption and planning implication of the sharing economy: a study of smart work in Canberra, Australia', International Journal of Knowledge-Based Development, Vol. 10, No. 4, pp.315-337.

Jang, S.C.S. and Park, K. (2019) 'A sustainable franchisor-franchisee relationship model: toward the franchise win-win theory', International Journal of Hospitality Management, January, Vol. 76, pp.13-24.

Kamble, R. and Wankhade, L. (2017) 'Perspectives on productivity: identifying attributes influencing productivity in various industrial sectors', Int. J. Productivity and Quality Management, Vol. 22, No. 4, pp.536-566.

Kantabutra, S. (2017) 'Exploring the corporate sustainability process: a Thai perspective', Int. J. Productivity and Quality Management, Vol. 22, No. 2, pp.170-189.

Kantabutra, S. (2019) 'People management for sustainable SMEs', Int. J. Productivity and Quality Management, Vol. 28, No. 4, pp.438-456. 
Karmeni, K., de la Villarmois, O. and Beldi, A. (2018) 'Impact of control on innovation: the case of franchising', Management Decision, Vol. 56, No. 7, pp.1485-1505, https://doi.org/10.1108/ MD-09-2015-0428.

Keshtidar, M., Sahebkaran, M.A., Talebpour, M. and Kalashi, M. (2018) 'Investigating the effect of brand identity and character on brand loyalty of football team fans', International Journal of Sport Management and Marketing, Vol. 18, Nos. 1-2, pp.105-115.

Kretinin, A., Anokhin, S. and Wincent, J. (2019) 'Exploring the antecedents of franchise internationalization', Journal of Business Research, https://doi.org/10.1016/j.jbusres. 2019.11.011.

Lertkornkitja, A. (2017) 'A comparative study of two Thai franchises in international expansion', International Journal of Services, Economics and Management, Vol. 8, Nos. 1-2, pp.51-72.

Liu, X. and Foreman, J. (2019) 'Exploring the impact of brand selfie on brand attitude in the Twittersphere', International Journal of Internet Marketing and Advertising, Vol. 13, No. 4, pp.321-337.

Maček, A., Kros, J. and Bobek, V. (2019) 'International franchising in the fashion industry from the franchisor perspective', Journal for International Business and Entrepreneurship Development, Vol. 12, No. 1, pp.49-66.

Media, K. (2016a) Waralaba di Indonesia Masih Didominasi 'Brand 'Asing, KOMPAS.com [online] https://money.kompas.com/read/2016/06/03/155107726/waralaba.di.indonesia.masih. didominasi.brand.asing (accessed 1 January 2020).

Media, K. (2016b) Waralaba Kuliner Cocok Dikembangkan di Kota-kota Ini. KOMPAS.com [online] https://yogyakarta.kompas.com/read/2016/09/05/201311426/waralaba.kuliner.cocok. dikembangkan.di.kembangkan-kota.ini (accessed 1 January 2020).

Minnema, A., Bijmolt, T.H.A. and Non, M.C. (2017) 'The impact of instant reward programs and bonus premiums on consumer purchase behavior', International Journal of Research in Marketing, Vol. 34, No. 1, pp.194-211.

Mishra, A. (2019) 'The media effect on individuals in the cultural transformation of Shekhawati Region: a case study', International Journal of Indian Culture and Business Management, Vol. 19, No. 3, pp.263-280.

Mishra, S., Raut, R.D., Narkhede, B.E., Gardas, B.B. and Priyadarshinee, P. (2018) 'To investigate the critical risk criteria of business continuity management by using analytical hierarchy process', International Journal of Management Concepts and Philosophy, Vol. 11, No. 1, pp.94-115.

Mohammed, A. and Ahmad, S. (2019) 'Café2Go: a struggle to build a local brand and stay ahead', Emerald Emerging Markets Case Studies, Vol. 9, No. 2, https://doi.org/10.1108/EEMCS-022019-0023.

Montoya, M.J.R. and Stasiewicz, C. (2020) 'Leveraging historical shifts in the world economy: systems of patronage and supportive ecosystems for creative and cultural enterprise', International Journal of Entrepreneurship and Small Business, Vol. 40, No. 2, pp.247-269.

Nyadzayo, M.W., Matanda, M.J. and Ewing, M.T. (2016) 'Franchisee-based brand equity: the role of brand relationship quality and brand citizenship behavior', Industrial Marketing Management, Vol. 52, pp.163-174, https://doi.org/10.1016/j.indmarman.2015.07.008.

Nyadzayo, M.W., Matanda, M.J. and Rajaguru, R. (2018) 'The determinants of franchise brand loyalty in B2B markets: an emerging market perspective', Journal of Business Research, Vol. 86, pp.435-445, https://doi.org/10.1016/j.jbusres.2017.09.015

Oh, D., Yoo, M.M. and Lee, Y. (2019) 'A holistic view of the service experience at coffee franchises: a cross-cultural study', International Journal of Hospitality Management, September, Vol. 82, pp.68-81.

Panda, S., Paswan, AK and Mishra, S.P. (2019) 'Impact of positioning strategies on franchise fee structure', Industrial Marketing Management, Vol. 81, pp.30-39, https://doi.org/10.1016/ j.indmarman.2018.10.001. 
Pansuwong, W. (2020) 'Business model and business model innovation: scholarly incongruence and implications to entrepreneurial firms', International Journal of Trade and Global Markets, Vol. 13, No. 1, pp.31-41.

Park, N. and Noh, H. (2018) 'Effects of mobile instant messenger use on acculturative stress among international students in South Korea', Computers in Human Behavior, Vol. 82, pp.34-43, https://doi.org/10.1016/j.chb.2017.12.033.

Perrigot, R. and Basset, G. (2018) 'Resale pricing in franchised stores: a franchisor perspective', Journal of Retailing and Consumer Services, Vol. 43, pp.209-217, https://doi.org/10.1016/ j.jretconser.2018.03.008.

Potdar, P.K., Routroy, S., and Behera, A. (2017) 'A benchmarking approach for enhancing agility in manufacturing environment', Int. J. Productivity and Quality Management, Vol. 20, No. 4, pp.488-512.

Rahatullah, M.K. and Raeside, R. (2018) 'Franchisee actions trigger franchisor power strategy alterations', Journal for International Business and Entrepreneurship Development, Vol. 11, No. 2, pp.140-162.

Ramesh, N. and Ravi, A. (2017) 'Enhancing the performance of micro, small and medium sized cluster organisation through lean implementation', Int. J. Productivity and Quality Management, Vol. 21, No. 3, pp.325-342.

Ranasinghe, R. and Li, C. (2017) 'Dimensions of mobilities, tourism and transition of cultural hegemony: a qualitative inquiry from Sri Lanka', International Journal of Tourism Anthropology, Vol. 6, No. 1, pp.21-40.

Roja, MP (2020) 'Excellence of social media: a quality assessment', International Journal of Business Excellence, Vol. 20, No. 1, pp.1-15.

Roussety, M., Frazer, L., Weaven, S. and Thaichon, P. (2020) 'Franchise risk ecology: a risk ecology for analyzing, mitigating, and pricing franchisee-contracted risks', in Ratten, V. (Ed.): Entrepreneurial Opportunities, pp.117-131, Emerald Publishing Limited, https://doi.org/ 10.1108/978-1-83909-285-520201009.

Santiago, M.C., Lanfranchi, A.G., Melo, PLDR, Carneiro-da-Cunha, J.A. and Telles, R. (2020) 'Socio-economic determinants of support and brand value perception: a survey of microfranchisees', International Journal of Services and Operations Management, Vol. 35, No. 3, pp.269-288.

Serrano, A.R. and Paul, J. (2018) 'A new conceptual model for international franchising', International Journal of Hospitality Management, Vol. 75, pp.179-188, https://doi.org/ 10.1016/j.ijhm.2018.05.024.

Shockley, J. and Turner, T. (2016) 'A relational performance model for developing innovation and long-term orientation in retail franchise organizations', Journal of Retailing and Consumer Services, Vol. 32, pp.175-188, https://doi.org/10.1016/j.jretconser.2016.06.013.

Short, J.C. Zachary, MA and KetchenJr, D.J. (2018) 'Entrepreneurial orientation rhetoric and franchise system size: the moderating role of military veteran recruitment', Journal of Business Venturing Insights, Vol. 10, https://doi.org/10.1016/j.jbvi.2018.e00097.

Sriram, K.V., Wadhwa, A., Rodrigues, L.L.R. and Mathew, A.O. (2018) 'Franchisee's perspective on factors influencing relationship development and performance in the Indian wellness industry', International Journal of Engineering Management and Economics, Vol. 6, Nos. 2-3, pp.95-110, https://doi.org/10.1504/IJEME.2018.095670.

Subawa, N.S. and Mimaki, C.A. (2019) 'E-marketplace acceptance of MSMEs in Bali based on performance expectancy and task technology fit', Proceedings of the 2019 2nd International Conference on E-Business, Information Management and Computer Science, pp.1-4, https://doi.org/10.1145/3377817.3377838.

Subawa, N.S. and Widhiasthini, N.W. (2019) Waralaba 4.0: Isu, Tren dan Evolusi Bisnis Waralaba di Era Digital, Books, Nilacakra, Badung.

Subawa, N.S. and Widhiasthini, N.W. (2020) 'Hegemony practice of consumers in disruption era', International Journal of Innovation, Creativity and Change, Vol. 11, No. 3, pp.357-375. 
Subawa, N.S., Widhiasthini, N.W., Pika, P.A.T.P. and Suryawati, P.I. (2020) 'Hedonism on the behavior of consumer society as a global cultural transformation', International Research Journal of Management, IT and Social Sciences, Vol. 7, No. 2, pp.59-70.

Sulhaini, Rusdan, Dayani, R., Sulaimiah and Ismiwati, B. (2019) 'Local brand origin knowledge of young consumers in a developing country', International Journal of Applied Management Science, Vol. 11, No. 1, pp.72-90.

Tournois, L. and Forterre, D. (2019) 'The extremes of franchising in a post-communist country', Journal of Business Strategy, Vol. 41 No. 3, pp.3-10, https://doi.org/10.1108/JBS-01-20190022 .

Tripathi, V., Roy, T. and Mishra, J. (2020) 'Is the lifestyle centre the new retail transformation in India? An exploratory study', International Journal of Business and Emerging Markets, Vol. 12, No. 2, pp.133-151.

Uli, L.D., Martín, F.V. and Cataluña, F.J.R. (2017) 'Analysis of efficiency of own and franchised units in the Spanish franchise system', European Research on Management and Business Economics, Vol. 23, No. 3, pp.165-172.

Weaven, S., Baker, B.L., Edwards, C., Frazer, L. and Grace, D. (2018) 'Predicting organizational form choice from pre-entry characteristics of franchisees', Australasian Marketing Journal, Vol. 26, No. 1, pp.49-58.

Wiese, N. (2017) 'The effects of institutional quality and market potential on the agglomeration of fast food franchises in Central America', Management Research, Vol. 15, No. 3, pp.268-291, https://doi.org/10.1108/MRJIAM-06-2017-0757.

Yakimova, R., Owens, M. and Sydow, J. (2019) 'Formal control influence on franchisee trust and brand-supportive behavior within franchise networks', Industrial Marketing Management, Vol. 76, pp.123-135, https://doi.org/10.1016/j.indmarman.2018.07.010.

Yunus, E.N. and Pamungkas, S.L. (2018) 'What does it take to become a lifestyle? A case of online-based transportation phenomenon', International Journal of Business Excellence, Vol. 16, No. 4, pp.407-426.

Zhu, Y. (2018) 'Lifestyle mobility: shifting conception of home in modern China', International Journal of Tourism Anthropology, Vol. 6, No. 4, pp.357-374. 